\title{
Laccase-Assisted Rapid Synthesis of Colloidal Gold Nanoparticles for the Catalytic Reduction of 4-Nitrophenol
}

\author{
Fang Li, ${ }^{a, \#}$ Zheng Li, ${ }^{b, c, \#}$ Chang Zeng ${ }^{c, \#}$ and Yonggang $\mathrm{Hu}^{*, b, c}$ \\ ${ }^{a}$ College of Food and Bioengineering, Henan University of Science and Technology, 471023 \\ Luoyang, China \\ ${ }^{b}$ State Key Laboratory of Agricultural Microbiology and ${ }^{c}$ College of Life Science and Technology, \\ Huazhong Agricultural University, 430070 Wuhan, China
}

\begin{abstract}
A green method for the rapid preparation of uniform-sized colloidal gold nanoparticles under ambient conditions was presented and validated using laccase as a reduction agent in alkaline medium. UV-Vis spectrophotometry, field-emission high-resolution transmission electron microscopy, X-ray diffraction, selected area electron diffraction, energy dispersive X-ray analysis, zetasizer, and Fourier transform infrared spectroscopy were used to characterize the gold nanoparticles. The gold nanoparticles were spherical, crystalline, uniform, and monodisperse with an average size of $12.24 \mathrm{~nm}$. These nanoparticles were successfully used to reduce 4-nitrophenol in the presence of $\mathrm{NaBH}_{4}$ and exhibited an excellent catalytic activity.
\end{abstract}

Keywords: colloidal gold nanoparticle, laccase, catalysis, 4-nitrophenol

\section{Introduction}

Over the past decade, gold nanoparticles (GNPs) have attracted considerable attention for their synthesis and application. Given their outstanding physicochemical and optoelectronic properties, ${ }^{1}$ GNPs have been widely used in spectroscopy, ${ }^{2}$ electrochemistry, ${ }^{3}$ catalysis,${ }^{4}$ biomedicine, ${ }^{5}$ and environmental biotechnology. ${ }^{6}$ Synthesizing GNPs with a tight control on their size and shape is crucial because these parameters determine material properties at the nanoscale. ${ }^{7-10}$ Various chemical and physical methods for the preparation of GNPs with controlled size and shape have been reported. ${ }^{4,10-15}$ However, the synthesis procedures for GNPs usually either involve the use of hazardous chemicals or the requirement of rigorous conditions, such as elevated temperature. ${ }^{14,15} \mathrm{~A}$ method employing enzymes as a template for the biosynthesis of GNPs ${ }^{16-26}$ has recently attracted increasing attention because of its simplicity ${ }^{1,26}$ and requirement for non-toxic chemicals. Moreover, enzymes can act as reducers and stabilizers because of their chemical, biochemical, and biological functions. For example, Sharma et al. ${ }^{19}$ used glucose oxidase (GOx) as the reducing agent to synthesize GNP-GOx composites

*e-mail: yongganghu@mail.hzau.edu.cn

\#These authors contributed equally to this work. and GNP-polyaniline nanocomposites. Venkatpurwar and Pokharkar ${ }^{20}$ reported a green method to prepare GNPs by using the therapeutic enzyme serratiopeptidase and demonstrated that the enzyme capped on the as-prepared GNPs retains its therapeutic activity. Zou et al. ${ }^{21}$ directly employed trypsin as the linking and reducing agent to synthesize gold nanoparticle-nanocluster composites.

Laccases ( $p$-diphenol: dioxygen oxidoreductase, EC 1.10.3.2) are blue multicopper oxidases that have been widely distributed in many eukaryotes [e.g., plants, ${ }^{27}$ insects, ${ }^{28}$ and fungi ${ }^{29}$ and prokaryotes (e.g., bacteria) $\left.{ }^{30}\right]$ since their discovery more than one century ago in the Japanese tree Rhus venicifera. Laccases generally show a high stability in the extracellular environment, and their purification is easy probably because most laccases are extracellular enzymes. ${ }^{31}$ As environmentally benign enzymes, laccases exhibit limitless applications in many fields, from textile to food industries, and from bioremediation processes to green synthesis. ${ }^{31-33}$ The use of laccase to synthesize GNPs was also studied. For example, Faramarzi and Forootanfar ${ }^{24}$ used laccase from Paraconiothyrium variabile to synthesize GNPs at $70{ }^{\circ} \mathrm{C}$ and obtained GNPs with sizes varying from 71 to $266 \mathrm{~nm}$. Guo et al. ${ }^{25}$ reported the use of laccase for the in situ synthesis of GNPs with an average size of $3 \pm 2 \mathrm{~nm}$ at $4{ }^{\circ} \mathrm{C}$ for $48 \mathrm{~h}$. Considering that the laccase-catalyzed reduction of $\mathrm{HAuCl}_{4}$ to GNPs can be 
accelerated in the presence of $\mathrm{NaOH}$, we proposed a simple, rapid, and eco-friendly method for the biosynthesis of monodispersed GNPs by using commercial laccase from Trametes versicolor. The synthesized GNPs were thoroughly characterized via UV-Vis spectrophotometry, field-emission high-resolution transmission electron microscopy (HRTEM), X-ray diffraction (XRD), selected area electron diffraction (SAED), energy dispersive X-ray analysis (EDXA), zetasizer, and Fourier transform infrared spectroscopy (FTIR). Furthermore, the Au-catalyzed reduction of 4-nitrophenol in the presence of $\mathrm{NaBH}_{4}$ was used as a model system to demonstrate that the GNPs are a promising catalyst.

\section{Experimental}

Materials

Laccase from T. versicolor was acquired from SigmaAldrich (St. Louis, MO, USA). $\mathrm{HAuCl}_{4} \cdot 3 \mathrm{H}_{2} \mathrm{O}$ powder and $\mathrm{NaOH}$ were purchased from Sinopharm Chemical Reagent Co., Ltd. (Shanghai, China). All chemical reagents were of analytical grade.

\section{Purification of laccase}

Laccase was purified according to our previously reported procedures. ${ }^{34} \mathrm{In}$ brief, $10.0 \mathrm{mg}$ of laccase was dissolved in $1.0 \mathrm{~mL}$ of $10.0 \mathrm{mmol} \mathrm{L}^{-1}$ sodium acetate buffer ( $\mathrm{pH}$ 5.5) and centrifuged using CR21G II high speed refrigerated centrifuge (Hitachi Ltd., Tokyo, Japan) at $14,000 \mathrm{rpm}$ for 1 hour at $4{ }^{\circ} \mathrm{C}$. The supernatant was subjected to a DEAE-SephadexA-50 (BioMan, Shanghai, China) anion-exchange column (previously equilibrated with buffer) at $4{ }^{\circ} \mathrm{C}$ and washed with buffer to remove unbound material. Laccase was eluted with $60.0 \mathrm{mmol} \mathrm{L}^{-1}$ ammonium sulfate, then desalted into $20.0 \mathrm{mmol} \mathrm{L}^{-1}$ sodium acetate buffer ( $\mathrm{pH} 5.5$ ), and stored at $4{ }^{\circ} \mathrm{C}$. The purified enzyme was applied for biosynthesis of GNPs.

\section{Synthesis of GNPs}

Purified laccase solution $\left(180.0 \mu \mathrm{L}, 0.575 \mathrm{mg} \mathrm{mL}^{-1}\right)$ was added to a solution containing $164.6 \mu \mathrm{L}$ of $24.3 \mathrm{mmol} \mathrm{L}^{-1}$ $\mathrm{HAuCl}_{4}$ and $50.0 \mu \mathrm{L}$ of $1.0 \mathrm{~mol} \mathrm{~L}^{-1} \mathrm{NaOH}$, and the volume was adjusted to $1.0 \mathrm{~mL}$ with ultrapure water. The mixture was incubated for 60.0 min under ambient conditions with mild stirring. Finally, the synthesized GNPs were purified via double centrifugation at $14,000 \mathrm{rpm}$ for $45 \mathrm{~min}$ at $4{ }^{\circ} \mathrm{C}$ to remove unbound laccase. Then, the GNPs were resuspended in ultrapure water for further characterization.

\section{Characterization of GNPs}

The UV-Vis spectra of the GNPs were recorded on an UV-Vis spectrometer (Ocean Optical QE65000, Ocean Optical Co., Ltd., Dunedin, USA). The The FTIR spectra of laccase and as-prepared GNPs were collected using an FTIR instrument (330 FTIR, Thermo Fisher Scientific, Waltham, MA, USA). Dried specimen was crushed with $\mathrm{KBr}$ in a mortar at 1:100 ratio. The pressed pellet was recovered with a clip and immediately analyzed in the 4000$400 \mathrm{~cm}^{-1}$ region over 500 scans in the FTIR instrument. The morphology of GNPs was recorded using a JEM-2100 HRTEM instrument (HR, JEOL Ltd., Tokyo, Japan) with an accelerating voltage of $200 \mathrm{kV}$. The atomic percentage was determined using the JEM-2100 HRTEM instrument equipped with an EDX system. The SAED patterns of the prepared TEM samples were also determined. Powder $\mathrm{X}$-ray diffraction was operated on an X-ray diffractometer (D/MAX-RB, Rigaku, Tokyo, Japan) at $40 \mathrm{kV}$ and $40 \mathrm{~mA}$ with $\mathrm{CuK} \alpha$ radiation. Size distribution was analyzed by Zetasizer (Nano-ZS90, Malvern Instrument Ltd., Malvern, Worcestershire, UK).

\section{Catalytic reduction of 4-nitrophenol}

The catalytic activity of the synthesized GNPs was researched by reducing 4-nitrophenol to 4-aminophenol with $\mathrm{NaBH}_{4}$ as the reducing agent. In brief, a reaction mixture of water $(1.38 \mathrm{~mL})$, aqueous 4 -nitrophenol solution $(50.0 \mu \mathrm{L}, 3.0 \mathrm{mmol} \mathrm{L}-1)$, and GNPs $(20.0 \mu \mathrm{L}$, $0.096 \mathrm{mmol} \mathrm{L}^{-1}$ ) was first collected in a quartz cuvette. The absorption spectrum was immediately recorded after the addition of $\mathrm{NaBH}_{4}\left(50.0 \mu \mathrm{L}, 0.3 \mathrm{~mol} \mathrm{~L}^{-1}\right)$.

\section{Results and Discussion}

\section{Biosynthesis of GNPs}

The parameters that affected the formation of GNPs by reducing $\mathrm{HAuCl}_{4}$ with laccase were investigated through UV-Vis spectroscopy. Alkaline condition was conducive to the synthesis and formation of GNPs. The concentrations of $\mathrm{NaOH}$ ranging from 0 to $90.0 \mathrm{mmol} \mathrm{L}^{-1}$ were added to adjust the reaction environment. As shown in Figure 1A, the absorption peak of the GNPs was not observed during $1 \mathrm{~h}$ in the absence of $\mathrm{NaOH}$. Interestingly, an obvious surface plasmon resonance (SPR) peak corresponding to the GNPs emerged in the presence of $\mathrm{NaOH}$. As expected, the intensities of the SPR band continuously increased with increasing $\mathrm{NaOH}$ and peaked at $50.0 \mathrm{mmol} \mathrm{L}^{-1}$. However, the intensities of the band did not change when the $\mathrm{NaOH}$ 
concentration was further increased. Thus, $50.0 \mathrm{mmol} \mathrm{L}^{-1}$ $\mathrm{NaOH}$ was selected for the subsequent synthesis. The GNPs yield increased with the increase of $\mathrm{AuCl}_{4}{ }^{-}$concentration from 0-4.0 $\mathrm{mmol} \mathrm{L}^{-1}$, and up to $4.0 \mathrm{mmol} \mathrm{L}^{-1}$ (Figure 1B). Accordingly, $4.0 \mathrm{mmol} \mathrm{L}^{-1}$ was used for the subsequent synthesis. The concentration of laccase was examined from 2.9 to $115.0 \mu \mathrm{g} \mathrm{mL}^{-1}$, and $103.5 \mu \mathrm{g} \mathrm{mL} \mathrm{m}^{-1}$ laccase was selected to be the optimum concentration (Figure 1C). Results in Figure 1D indicate that the temperature in the range of 20 to $80^{\circ} \mathrm{C}$ did not contribute to the change in SPR band. In other words, the size and yield of GNPs affected by the temperature is not obvious. As a result, the GNPs could be easily synthesized at room temperature $\left(25^{\circ} \mathrm{C}\right)$. In addition, the reaction time was also investigated in the range of 0.0 to $90.0 \mathrm{~min}$. As shown in Figure 1E, the yield of GNPs increased with time, peaked at $60.0 \mathrm{~min}$, and then plateaued. Thus, the reaction solution containing $50.0 \mathrm{mmol} \mathrm{L}^{-1}$ $\mathrm{NaOH}, 4.0 \mathrm{mmol} \mathrm{L}^{-1} \mathrm{AuCl}_{4}^{-}$, and $103.5 \mu \mathrm{g} \mathrm{mL}^{-1}$ laccase incubated at ambient temperature for $60.0 \mathrm{~min}$ was selected for the biosynthesis of GNPs. As shown in Table 1, the present method was quick and facile in comparison with other chemical synthesis and biosynthesis methods. This result indicates that the developed method is a promising candidate for the rapid preparation of GNPs.

\section{Characterization}

UV-Vis spectroscopy is a primary technique for the characterization of metallic nanoparticles largely attributed to SPR phenomenon. The color of the as-prepared nanoparticles changed from yellow to deep wine because of the collective oscillation of free electrons induced by an interacting electromagnetic field in GNPs, indicating the formation of GNPs. Figure 2A shows that the synthesized GNPs displayed a single but strong SPR band at $518 \mathrm{~nm}$. The XRD pattern (Figure 2B) consists of four prominent Bragg reflections at $2 \theta$ values of $38.1,44.3,64.5$, and $77.6^{\circ}$, which corresponded to the (111), (200), (220), and (311) lattice planes of the face-centered cubic (fcc) structure of gold, implying the formation of crystalline gold in the specimen. The TEM (Figure 2C) and HRTEM (Figure 2D) images of the GNPs clearly indicate that the composites were uniform and had a spherical morphology with good dispersion. The clear lattice fringes in the GNPs were observed in the HRTEM image, and the interfringe spacing was $0.23 \mathrm{~nm}$, which is close to the interplane distance of the (111) plane in the fcc gold. The SAED pattern of GNPs (Figure 2E) further confirmed that the GNPs were nanocrystalline in nature and that the structure was fcc type, which was in accordance with the XRD result. The particle size distribution of the GNPs was analyzed using a Zetasizer (Figure 2F) and found to range from 10.10 to $13.54 \mathrm{~nm}$ with an average of approximately $12.24 \mathrm{~nm}$.

The elemental composition of the as-prepared GNPs was determined through EDXA analysis. As shown in Figure $3 \mathrm{~A}$, two characteristic peaks of gold atoms at approximately 2.195 and $9.700 \mathrm{keV}$ showed the presence of gold. The $\mathrm{C}, \mathrm{N}$, and $\mathrm{O}$ signals may originate from the
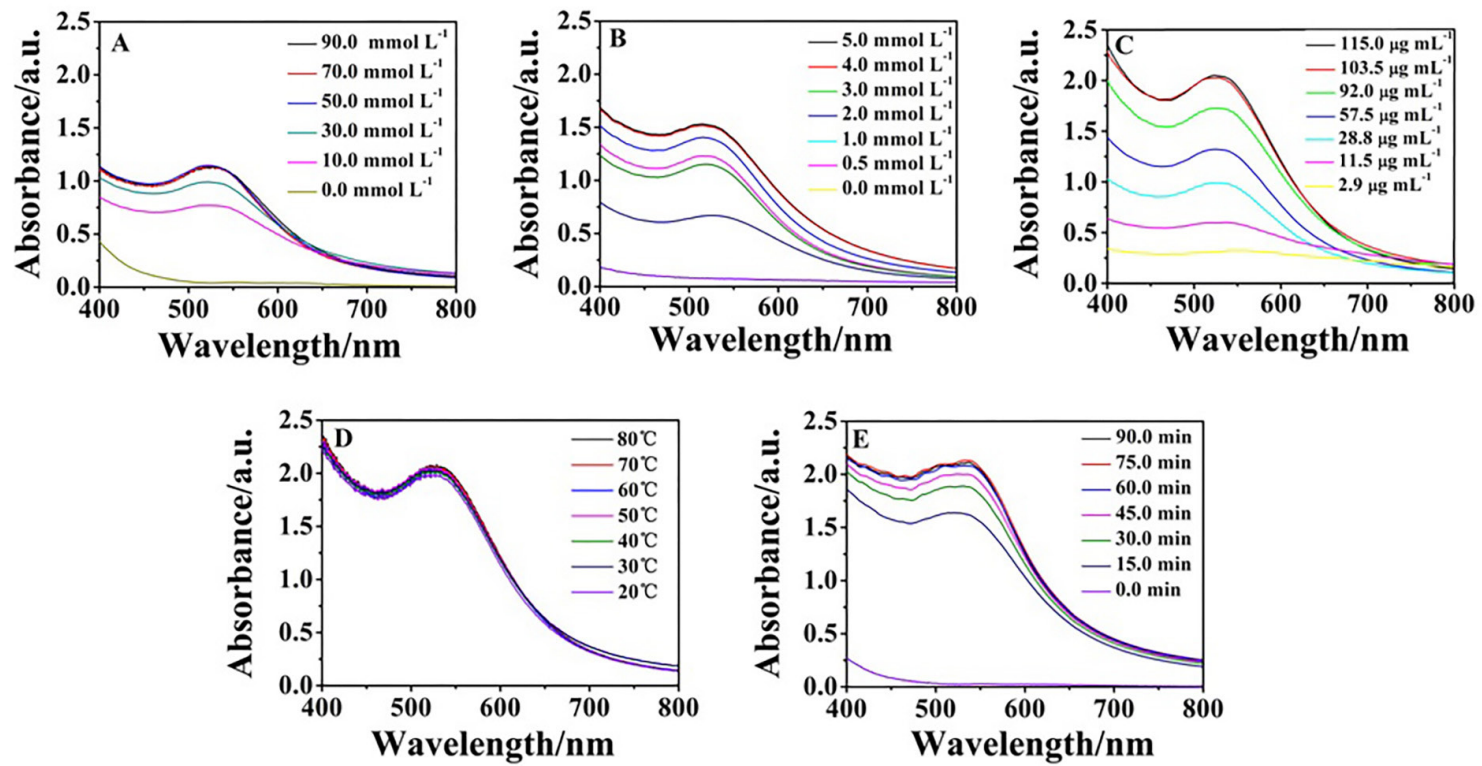

Figure 1. Effect of experimental conditions on the biosynthesis of GNPs. (A) Effect of $\mathrm{NaOH}$ concentration, the solution containing $1.0 \mathrm{mmol} \mathrm{L}^{-1} \mathrm{HAuCl}_{4}$, $23.0 \mu \mathrm{g} \mathrm{mL}-1$ laccase, and $\mathrm{NaOH}$ was incubated at $30^{\circ} \mathrm{C}$ for $60.0 \mathrm{~min}$; (B) effect of $\mathrm{HAuCl}_{4}$ concentration, the solution containing $\mathrm{HAuCl}_{4}, 23.0 \mu \mathrm{g} \mathrm{mL} \mathrm{m}^{-1}$ laccase, and $50.0 \mathrm{mmol} \mathrm{L}^{-1} \mathrm{NaOH}$ was incubated at $30^{\circ} \mathrm{C}$ for $60.0 \mathrm{~min}$; (C) effect of laccase concentration, the solution containing $4.0 \mathrm{mmol} \mathrm{L}^{-1} \mathrm{HAuCl}_{4}$, laccase, and $50.0 \mathrm{mmol} \mathrm{L}{ }^{-1} \mathrm{NaOH}$ was incubated at $30^{\circ} \mathrm{C}$ for $60.0 \mathrm{~min}$; (D) effect of reaction temperature, the optimal solution was incubated for 60.0 min; (E) effect of reaction time, the optimal solution was incubated at room temperature. 
Table 1. Comparison of reaction conditions for the preparation of GNPs

\begin{tabular}{|c|c|c|}
\hline Reductant & Reaction condition & Reference \\
\hline Trisodium citrate & $\begin{array}{l}\text { the solution containing } 0.02 \% \mathrm{HAuCl}_{4}+0.08 \% \text { trisodium citrate was microwave-assisted heated with } \\
\qquad 120 \mathrm{~W} \text { power for } 15.0 \mathrm{~min}\end{array}$ & 4 \\
\hline $\mathrm{NaBH}_{4}$ & $\begin{array}{l}\text { the solution containing } 0.02 \mathrm{~g} \mathrm{~mL}^{-1} \mathrm{PVP}, 2.0 \mathrm{~mL} \text { of } 0.024 \mathrm{~mol} \mathrm{~L}^{-1} \text { and } 1.0 \mathrm{~mL} \text { of } 0.0167 \mathrm{~g} \mathrm{NaBH}_{4} \\
\text { was incubated at } 170{ }^{\circ} \mathrm{C} \text { for } 3.0 \mathrm{~h}\end{array}$ & 14 \\
\hline URAK & $\begin{array}{l}\text { the solution containing } 1.0 \mathrm{mg} \mathrm{mL}^{-1} \mathrm{URAK} \text { and } 1.0 \mathrm{mmol} \mathrm{L}^{-1} \mathrm{HAuCl}_{4} \text { in } 10.0 \mathrm{mmol} \mathrm{L}^{-1} \text { Tris- } \mathrm{HCl} \text { buffer }(\mathrm{pH}=9.0) \\
\text { was incubated at } 37^{\circ} \mathrm{C} \text { for } 60.0 \mathrm{~h}\end{array}$ & 17 \\
\hline Glucose oxidase & $\begin{array}{l}\text { the solution containing } 6 \times 10^{-4} \mathrm{~mol} \mathrm{~L}^{-1} \mathrm{HAuCl}_{4} \text { and } 3.0 \mathrm{~mL} \text { of } 0.7 \mathrm{mg} \mathrm{mL}^{-1} \text { glucose oxidase in } \\
\qquad 10.0 \mathrm{mmol} \mathrm{L}^{-1} \mathrm{PBS}(\mathrm{pH}=7.0) \text { was incubated at } 37^{\circ} \mathrm{C} \text { for } 36.0 \mathrm{~h}\end{array}$ & 19 \\
\hline Trypsin & $\begin{array}{l}\text { the solution containing } 4.0 \mathrm{mmol} \mathrm{L}^{-1} \mathrm{HAuCl}_{4} \text { and } 20.0 \mathrm{mg} \mathrm{mL}^{-1} \text { trypsin }(\mathrm{pH}=12.0) \text { was incubated at } \\
\qquad 37^{\circ} \mathrm{C} \text { for } 510.0 \mathrm{~min}\end{array}$ & 21 \\
\hline Laccase & $\begin{array}{l}\text { the solution containing } 0.5 \mathrm{~mL} \text { of } 8.0 \mathrm{mg} \mathrm{mL}^{-1} \text { laccase and } 2.5 \mathrm{~mL} \text { of } 0.6 \mathrm{~mol} \mathrm{~L}^{-1} \mathrm{HAuCl}_{4} \text { was incubated at } \\
70^{\circ} \mathrm{C} \text { for } 20.0 \mathrm{~min}\end{array}$ & 24 \\
\hline Laccase & $\begin{array}{l}\text { the solution containing } 0.125 \mathrm{mg} \mathrm{mL}^{-1} \text { laccase and } 0.5 \mathrm{mmol} \mathrm{L}^{-1} \mathrm{HAuCl}_{4} \text { in } \mathrm{PB} \text { buffer }(\mathrm{pH}=6.0) \\
\text { was incubated at } 4{ }^{\circ} \mathrm{C} \text { for } 48 \mathrm{~h}\end{array}$ & 25 \\
\hline$\alpha$-Amylase & $\begin{array}{l}\text { the solution containing } 4.5 \times 10^{-4} \mathrm{~mol} \mathrm{~L}^{-1} \mathrm{HAuCl}_{4} \text { and } 1.0 \mathrm{mg} \mathrm{mL}^{-1} \alpha \text {-amylase in } 10.0 \mathrm{mmol} \mathrm{L}^{-1} \mathrm{PBS}(\mathrm{pH}=7.0) \\
\text { was incubated at } 37^{\circ} \mathrm{C} \text { for } 48 \mathrm{~h}\end{array}$ & 35 \\
\hline
\end{tabular}
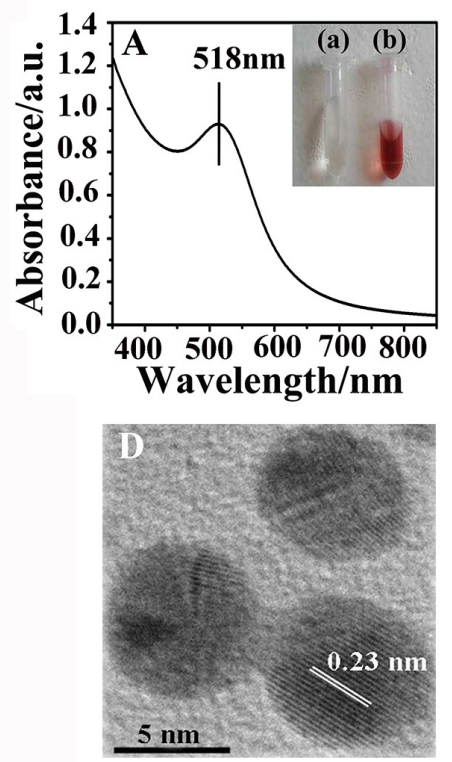
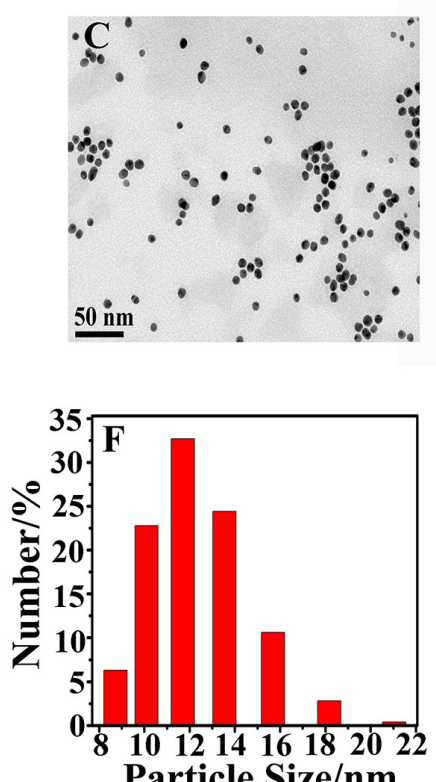

Figure 2. (A) UV-Vis absorption spectra of GNPs synthesized by laccase. Inset shows (a) the control sample (the solution containing $50.0 \mathrm{mmol} \mathrm{\textrm {L } ^ { - 1 }} \mathrm{NaOH}$ $4.0 \mathrm{mmol} \mathrm{L}^{-1} \mathrm{AuCl}_{4}{ }^{-}$and $103.5 \mu \mathrm{g} \mathrm{mL}{ }^{-1}$ laccase was incubated at ambient temperature for $0.0 \mathrm{~min}$ ) and (b) GNPs (the same solution was incubated at ambient temperature for $60.0 \mathrm{~min}$ ); (B) XRD spectrum of GNPs; (C) TEM image of GNPs; scale bar: $50 \mathrm{~nm}$; (D) HRTEM image of GNPs showing lattice separation; scale bar: $5 \mathrm{~nm}$; (E) SAED pattern of GNPs; scale bar: $5 \mathrm{~nm}^{-1}$ and (F) particle size distribution of GNPs.

laccases bound to the surface of GNPs, whereas the $\mathrm{Cu}$ and some of the $\mathrm{C}$ in the EDS spectrum might be attributed to the TEM grid background.

FTIR analysis of laccase and GNPs was further carried out (Figure 3B). The FTIR spectrum of laccase showed NH and $\mathrm{OH}$ bands at $3417.7 \mathrm{~cm}^{-1}, \mathrm{COO}^{-}$stretching at 1727.9 and $1403.4 \mathrm{~cm}^{-1}$, amide I band at $1617.7 \mathrm{~cm}^{-1}$, amide III band at $1263.0 \mathrm{~cm}^{-1}, \mathrm{P}-\mathrm{OH}$ at $1075.4 \mathrm{~cm}^{-1}$, and $\mathrm{P}-\mathrm{O}-\mathrm{C}$ at
$1037.5 \mathrm{~cm}^{-1}$ (black line). The adsorption band of $\mathrm{P}-\mathrm{OH}$ and $\mathrm{P}-\mathrm{O}-\mathrm{C}$ stretching signified the presence of protein phosphate groups and the adsorption band of the $\mathrm{COO}^{-}$derived from the carboxyl side groups in the amino acid residues. The spectrum of GNPs (red line) has similar FTIR bands to that of laccase. However, the wavenumber corresponding to the asymmetric stretching mode of the $\mathrm{COO}^{-}$group shifted from 1727.9 to $1420.9 \mathrm{~cm}^{-1}$, whereas that corresponding to the 

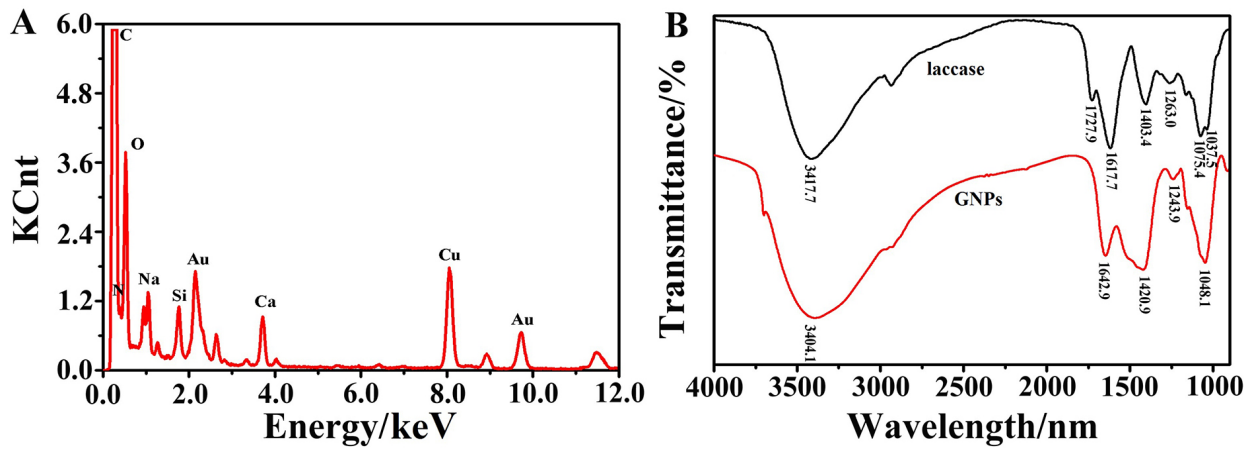

Figure 3. (A) EDXA spectrum of GNPs; (B) FTIR spectrum of laccase (black line) and GNPs (red line).

NH stretching vibration shifted from 3417.7 to $3404.1 \mathrm{~cm}^{-1}$. The adsorption band of amide I changed from 1617.7 to $1642.9 \mathrm{~cm}^{-1}$. Meanwhile, the adsorption bands of $\mathrm{P}-\mathrm{OH}$ and $\mathrm{P}-\mathrm{O}-\mathrm{C}$ disappeared while a new band appeared at $1048.1 \mathrm{~cm}^{-1}$. Figure 3 indicates that GNP-laccase composites were formed during our experiments.

\section{Catalytic reduction of 4-nitrophenol}

To evaluate the catalytic activity, the reduction of 4-nitrophenol to 4-aminophenol in the presence of $\mathrm{NaBH}_{4}$ was selected as the model system. ${ }^{36}$ The SPR band of 4-nitrophenol immediately shifted from 317 to 400 upon the addition of fleshly prepared $\mathrm{NaBH}_{4}$ solution with an associated color change from light yellow to bright yellow, implying the formation of 4-nitrophenolate ions. The addition of excess $\mathrm{NaBH}_{4}$ solution exerted no change on the SPR band at $400 \mathrm{~nm}$. Interestingly, the color gradually faded away with the addition of GNPs, and this process lasted for approximately $5 \mathrm{~min}$. Similarly, this phenomenon was clearly observed by the gradual disappearance of the SPR band at $400 \mathrm{~nm}$ after the addition of $4.82 \times 10^{-6} \mathrm{mmol} \mathrm{L}^{-1}$ GNPs with a concurrent appearance of a new peak at $300 \mathrm{~nm}$, which corresponded to the formation of 4-aminophenol (Figure 4A).

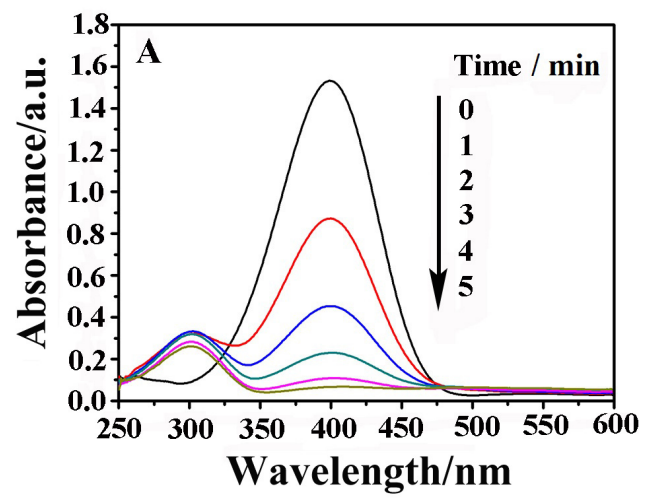

Furthermore, the kinetics of the GNP-catalyzed reaction of 4-nitrophenol was investigated. Since the amount of $\mathrm{NaBH}_{4}$ largely exceeded in the reaction, the reduction rate can be assumed to be independent of $\mathrm{NaBH}_{4}$ concentration. Thus, the catalytic reaction could be treated as pseudo-firstorder kinetics with respect to 4-nitrophenol concentration. The values of the apparent reaction rate constant $k$ of these catalytic reactions in the presence of different doses of the as-prepared nanocomposites were calculated from the plot of $\ln$ A vs. time (Figure 4B), where A is the absorbance at $400 \mathrm{~nm}$ of 4-nitrophenolate ions. The rate constant $k$ gradually increased with increasing GNPs and reached $0.745 \mathrm{~min}^{-1}$ after using $7.712 \times 10^{-6} \mathrm{mmol} \mathrm{L}^{-1}$ catalyst, which was found to be significantly superior to those of most relevant literature reports for the reduction of 4-nitrophenol (Table 2). The GNPs could be stably stored in aqueous medium for as long as 3 months, and remained well dispersive without aggregation after reaction. The excellent stability and high catalytic activity of the GNPs probably attributed to the formation of GNP-laccase composites (Figure 3). The laccase, as a stabilizer, could resist the aggregation of GNPs to bulk materials, which leads to the loss of the catalytic activity of nanoparticles. ${ }^{37}$ Moreover, the abundant function groups $(-\mathrm{OH},-\mathrm{COOH}$, and $-\mathrm{C}=\mathrm{O})$ derived from laccase can increase the adsorption capacity,

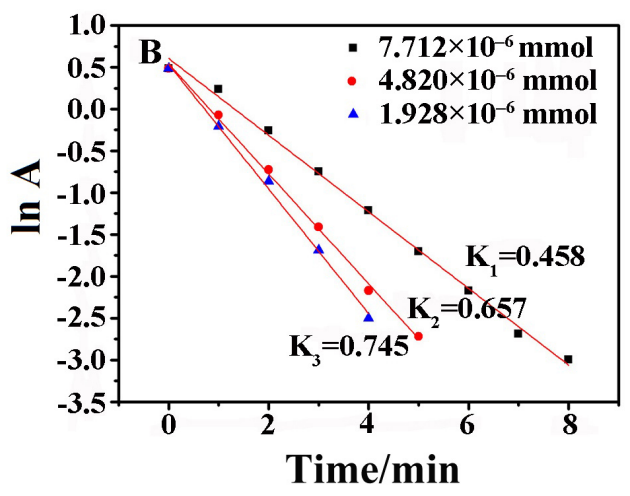

Figure 4. (A) Time-dependent absorption spectra for the catalytic reduction of 4-nitrophenol by $\mathrm{NaBH}_{4}$ in the presence of GNPs synthesized by laccase; (B) plot of $\ln \mathrm{A}$ ( $\mathrm{A}=$ absorbance at $400 \mathrm{~nm}$ of 4-nitrophenolate ion) versus time. 
Table 2. A comparison between the proposed system and literature reports for the room-temperature reduction of 4-nitrophenol

\begin{tabular}{|c|c|c|c|}
\hline Catalyst & Reaction condition & $k / \min ^{-1}$ & Reference \\
\hline GNP-glucose oxidase & $\begin{array}{c}1.0 \mathrm{mg} \text { of } \mathrm{NaBH}_{4}, 2.5 \mathrm{~mL} \text { of } \\
0.12 \mathrm{mmol} \mathrm{L}^{-1} 4-\mathrm{NP}, 0.005 \mathrm{mmol} \mathrm{L}^{-1} \mathrm{Au}\end{array}$ & 0.252 & 19 \\
\hline GNP-carbon dots & $\begin{array}{l}1.0 \mathrm{~mL} \text { of } 0.33 \mathrm{~mol} \mathrm{~L}^{-1} \mathrm{NaBH}_{4}, 2.0 \mathrm{~mL} \text { of } \\
3.0 \mathrm{mmol} \mathrm{L}^{-1} 4-\mathrm{NP}, 1.25 \mathrm{mmol} \mathrm{L}^{-1} \mathrm{Au}\end{array}$ & 0.68 & 38 \\
\hline Au cluster & $\mathrm{NaBH}_{4}: 4-\mathrm{NP} 30: 1 ;[\mathrm{Au}]: 4-\mathrm{NP} 1: 105$ & 0.51 & 39 \\
\hline Ferric ammonium citrate-synthesized GNPs & $\begin{array}{c}0.1 \mathrm{~mL} \text { of } 3.0 \mathrm{mmol} \mathrm{L}^{-1} 4-\mathrm{NP} \\
0.1 \mathrm{~mL} 0.3 \mathrm{~mol} \mathrm{~L}^{-1} \mathrm{NaBH}_{4}, 0.0115 \mathrm{mmol} \mathrm{L}-1 \mathrm{Au}\end{array}$ & 0.66 & 40 \\
\hline Gold nano-bioconjugates & $\begin{array}{c}10.0 \mathrm{mmol} \mathrm{L}^{-1} \mathrm{NaBH}_{4}, 0.1 \mathrm{mmol} \mathrm{L}^{-1} 4-\mathrm{NP} \\
0.0101 \mathrm{mmol} \mathrm{L}^{-1} \mathrm{Au}\end{array}$ & $0.17-0.73$ & 41 \\
\hline Glucomannan-synthesized GNPs & $\begin{array}{c}10.0 \mathrm{mmol} \mathrm{L}^{-1} \mathrm{NaBH}_{4}, 0.05 \mathrm{mmol} \mathrm{L}^{-1} 4-\mathrm{NP} \\
15.0 \mu \mathrm{L} \text { of GNPs }\end{array}$ & 0.362 & 42 \\
\hline GNPs synthesized with fruit extract (Prunus domestica) & $\begin{array}{l}0.08 \mathrm{~mL} \text { of } 0.3 \mathrm{~mol} \mathrm{~L}^{-1} \mathrm{NaBH}_{4}, 2.0 \mathrm{~mL} \text { of } \\
10^{-4} \mathrm{~mol} \mathrm{~L}^{-1} 4-\mathrm{NP}, 0.05-0.2 \mathrm{~mL} \text { of GNPs }\end{array}$ & $0.114-0.306$ & 43 \\
\hline Au-calcium alginate composite & $0.1 \mathrm{~mol} \mathrm{~L}^{-1} \mathrm{NaBH}_{4}, 0.1 \mathrm{mmol} \mathrm{L}^{-1} 4-\mathrm{NP}, 2.0 \mathrm{~g} \mathrm{~L}^{-1} \mathrm{Au}$ & $0.014-0.020$ & 44 \\
\hline$\alpha$-Cyclodextrin-coated GNPs & $\begin{array}{c}1.0 \mathrm{~mL} \text { of } 0.015 \mathrm{~mol} \mathrm{~L}^{-1} \mathrm{NaBH}_{4}, 1.7 \mathrm{~mL} \text { of } \\
0.2 \mathrm{mmol} \mathrm{L}^{-1} 4-\mathrm{NP}, 0.3 \mathrm{~mL} \text { of } 0.2 \mathrm{mmol} \mathrm{L}^{-1} \mathrm{Au}\end{array}$ & $0.179-0.274$ & 45 \\
\hline GNPs & $\begin{array}{c}1.38 \mathrm{~mL} \text { of } \mathrm{H}_{2} \mathrm{O}, 50 \mu \mathrm{L} \text { of } 0.3 \mathrm{~mol} \mathrm{~L}^{-1} \mathrm{NaBH}_{4}, 50.0 \mu \mathrm{L} \text { of } \\
3.0 \mathrm{mmol} \mathrm{L}^{-1} 4-\mathrm{NP}, 20.0 \mu \mathrm{L} \text { of } 0.096 \mathrm{mmol} \mathrm{L}^{-1} \mathrm{Au}\end{array}$ & 0.745 & this work \\
\hline
\end{tabular}

4-NP: 4-Nitrophenol; GNPs: gold nanoparticles; $k$ : rate constant.

and accelerate the reduction rate, eventually enhance the catalytic acitivity. ${ }^{38}$ These results demonstrate that the GNPs prepared by the proposed method are the promising catalyst.

\section{Conclusions}

We developed a simple, quick, and eco-friendly method to biosynthesize well-dispersed GNPs by using laccase as both reducing and stabilizing reagents. The synthesis was carried out for $60 \mathrm{~min}$ in alkaline solution under ambient conditions. The prepared GNPs exhibited an uniform spherical shape, narrow size distribution, and excellent storage stability. The obtained GNPs served as an efficient catalyst in the borohydride reduction of 4-nitrophenol. In consideration of the huge potential of nano-composite materials in various applications, the development of the biogenic route using laccase as a template under ambient conditions will offer a green alternative toward the formation of gold nanoparticles.

\section{Acknowledgments}

This work was supported by the National Natural Science Foundation of China (Grant No. 31501563), the State Key Laboratory of Agricultural Microbiology, Huazhong Agricultural University (Grant No. AMLKF201405) and the Opening Foundation of State Key Laboratory of Agricultural Microbiology (Grant No. AMLKF201508).

\section{References}

1. Panda, T.; Deepa, K.; J. Nanosci. Nanotechnol. 2011, 11, 10279.

2. Schmit, V. L.; Martoglio, R.; Scott, B.; Strickland, A. D.; Carron, K. T.; J. Am. Chem. Soc. 2012, 134, 59.

3. Du, L.; Jiang, H.; Liu, X.; Wang, E.; Electrochem. Commun. 2007, 9, 1165.

4. Du, J.; Xia, Z.; Anal. Methods 2013, 5, 1991.

5. Dykman, L.; Khlebtsov, N.; Chem. Soc. Rev. 2012, 41, 2256.

6. Das, S. K.; Das, A. R.; Guha, A. K.; Langmuir 2009, 25, 8192.

7. Daniel, M.-C.; Astruc, D.; Chem. Rev. 2004, 104, 293.

8. Campelo, J. M.; Luna, D.; Luque, R.; Marinas, J. M.; Romero, A. A.; ChemSusChem 2009, 2, 18.

9. White, R. J.; Budarin, V. L.; Clark, J. H.; ChemSusChem 2008 , $1,408$.

10. Sánchez-Iglesias, A.; Pastoriza-Santos, I.; Pérez-Juste, J.; Rodríguez-González, B.; García deAbajo, F. J.; Liz-Marzán, L. M.; Adv. Mater. 2006, 18, 2529.

11. Teranishi, T.; Hasegawa, S.; Shimizu, T.; Miyake, M.; Adv. Mater. 2001, 13, 1699.

12. Ruan, Q.; Shao, L.; Shu, Y.; Wang, J.; Wu, H.; Adv. Opt. Mater. 2014, 2, 65 .

13. Zhang, L.; Xia, K.; Lu, Z.; Li, G.; Chen, J.; Deng, Y.; Li, S.; Zhou, F.; He, N.; Chem. Mater. 2014, 26, 1794.

14. Zhao, F.; Yang, Y.; J. Dispersion Sci. Technol. 2010, 31, 471.

15. Brust, M.; Walker, M.; Bethell, D.; Schiffrin, D. J.; Whyman, R.; J. Chem. Soc., Chem. Commun. 1994, 801.

16. Sharma, B.; Mandani, S.; Sarma, T. K.; Sci. Rep. 2013, 3, 2601. 
17. Deepak, V.; Umamaheshwaran, P. S.; Guhan, K.; Nanthini, R. A.; Krithiga, B.; Jaithoon, N. M.; Gurunathan, S.; Colloids Surf., B 2011, 86, 353.

18. Govindaraju, K.; Kiruthiga, V.; Manikandan, R.; Ashokkumar, T.; Singaravelu, G.; Mater. Lett. 2011, 65, 256.

19. Sharma, B.; Mandani, S.; Sarma, T. K.; J. Mater. Chem. B 2014, 2,4072 .

20. Venkatpurwar, V. P.; Pokharkar, V. B.; J. Biomed. Nanotechnol. 2010, 6, 667.

21. Zou, L.; Qi, W.; Huang, R.; Su, R.; Wang, M.; He, Z.; ACS Sustainable Chem. Eng. 2013, 1, 1398.

22. Bharde, A.; Kulkarni, A.; Rao, M.; Prabhune, A.; Sastry, M.; J. Nanosci. Nanotechnol. 2007, 7, 4369.

23. Sun, J.; Ge, J.; Liu, W.; Lan, M.; Zhang, H.; Wang, P.; Wang, Y.; Niu, Z.; Nanoscale 2014, 6, 255.

24. Faramarzi, M. A.; Forootanfar, H.; Colloids Surf., B 2011, 87, 23.

25. Guo, S.; Li, H.; Liu, J.; Yang, Y.; Kong, W.; Qiao, S.; Huang, H.; Liu, Y.; ACS Appl. Mater. Interfaces 2015, 37, 20937.

26. Tikariha, S.; Singh, S.; Banerjee, S.; Vidyarthi, A. S.; Int. J. Pharm. Sci. Res. 2012, 3, 1603.

27. McCaig, B. C.; Meagher, R. B.; Dean, J. F.; Planta 2005, 221, 619.

28. Dittmer, N. T.; Suderman, R. J.; Jiang, H.; Zhu, Y. C.; Gorman, M. J.; Kramer, K. J.; Kanost, M. R.; Insect Biochem. Mol. Biol. 2004, 34, 29.

29. Dwivedi, U. N.; Singh, P.; Pandey, V. P.; Kumar, A.; J. Mol. Catal. B: Enzym. 2011, 68, 117.

30. Alexandre, G.; Zhulin, I. B.; Trends Biotechnol. 2000, $18,41$.

31. Rodgers, C. J.; Blanford, C. F.; Giddens, S. R.; Skamnioti, P.; Armstrong, F. A.; Gurr, S. J.; Trends Biotechnol. 2010, 28, 63.
32. Riva, S.; Trends Biotechnol. 2006, 24, 219.

33. Alcalde, M.; Ferrer, M.; Plou, F. J.; Biocatal. Biotransform. 2007, 25, 113.

34. Zhang, Y.; Tan, C.; Fei, R.; Liu, X.; Zhou, Y.; Chen, J.; Chen, H.; Zhou, R.; Hu, Y.; Anal. Chem. 2014, 86, 1115.

35. Rangnekar, A.; Sarma, T. K.; Singh, A. K.; Deka, J.; Ramesh, A.; Chattopadhyay, A.; Langmuir 2007, 23, 5700.

36. Al-Naji, M.; Balu, A. M.; Roibu, A.; Goepel, M.; Einicke, W.; Luque, R.; Glaser, R.; Catal. Sci. Technol. 2015, 5, 2085.

37. Watt, J.; Cheong, S.; Toney, M. F.; Ingham, B.; Cookson, J.; Bishop, P. T.; Tilley, R. D.; ACS Nano 2010, 4, 396.

38. Liu, R.; Liu, J.; Kong, W.; Huang, H.; Han, X.; Zhang, X.; Liu, Y.; Kang, Z.; Dalton Trans. 2014, 43, 10920.

39. Shivhare, A.; Ambrose, S. J.; Zhang, H.; Purves, R. W.; Scott, R. W.; Chem. Commun. 2013, 49, 276.

40. Rashid, M. H.; Mandal, T. K.; Adv. Funct. Mater. 2008, 18, 2261.

41. Das, S. K.; Dickinson, C.; Lafir, F.; Brougham, D. F.; Marsili, E.; Green Chem. 2012, 14, 1322.

42. Gao, Z.; Su, R.; Huang, R.; Qi, W.; He, Z.; Nanoscale Res. Lett. 2014, 9, 404.

43. Dauthal, P.; Mukhopadhyay, M.; Ind. Eng. Chem. Res. 2012, 51, 13014.

44. Saha, S.; Pal, A.; Kundu, S.; Basu, S.; Pal, T.; Langmuir 2010 , $26,2885$.

45. Huang, T.; Meng, F.; Qi, L.; J. Phys. Chem. C 2009, 113, 13636.

Submitted: April 20, 2016

Published online: August 30, 2016 